ヒトや野生生物における医薬品, 環境化学物質の安全性評価の精度向上にむけて 一代謝的活性化, 種差, エピジェネティクスの観点から一

佐 能 正 剛, ${ }^{*}, a$ 木 村 朋 紀 $b$

\title{
Further Improvement of Risk Assessment of Pharmaceutical and Chemicals in Humans and Animals - From the View Point of Metabolic Activation, Species Differences, and Epigenetic Regulation-
}

\author{
Seigo Sanoh ${ }^{*, a}$ and Tomoki Kimura ${ }^{b}$
}

${ }^{a}$ Graduate School of Biomedical and Health Sciences, Hiroshima University; 1-2-3 Kasumi, Minami-ku, Hiroshima 734-8553, Japan: and ${ }^{b}$ Department of Life Science, Setsunan University; 17-8 Ikedanaka-machi, Neyagawa, Osaka 572-8508, Japan.

医薬品や一般化学物質の安全性・毒性は，基本的 に実験動物での試験結果から見積もられているが, その感受性には種差があり, 精度の高い毒性・安全 性評価はいまだに難しい。ヒトにおける毒性を見積 もるにあたり，ヒト由来細胞を用いた in vitro 毒性 評価も有用であるが，in vivo での毒性との乘離を 考慮しなければならない。

また, 一方で化学物質による大気, 土壌, 水環境 中污染も問題となっている.「人の健康及び生態系 に影響を及ぼすおそれがある化学物質による環境の 污染を防止することを目的とする法律」として化審 法があるように，化学物質の影響を考慮すべき対象 はヒトだけではなく, 野生生物にも目を向ける必要 がある. しかしながら，化学物質感受性を規定する 要因には様々なものがあり, これらの統合的理解に は至っていない。医薬品や一般化学物質の有用性と 毒性のバランスを考慮する上でも，ヒトや野生生物 における安全性評価の精度向上は重要な課題となる が，これらの要因がその精度向上の壁となっている と考えられる.

実験動物における反復投与毒性試験における最大 無毒性量から安全係数を考慮に入れた化学物質（農 薬，食品添加物など）の 1 日摂取許容量が設定され ている。一方, 創薬においても実験動物による反復 投与毒性試験から, 推定臨床用量を踏まえながら十

a広島大学大学院医歯薬保健学研究院（干734-8553 広 島市南区霞 $1-2-3), b$ 摂南大学理工学部生命科学科 (T572-8508 大阪府寝屋川市池田中町 17-8)

*e-mail: sanoh@hiroshima-u.ac.jp

日本薬学会第 136 年会シンポジウム S66 序文
分な安全係数が確保できる医薬品候補化合物を選択 している.

この安全係数には，種差や個人差が考慮されてい るが, その種差の要因として異物代謝反応の活性差 が挙げられ，個体差の要因には遺伝子素因や環境要 因による感受性変化などが考えられる。また野生生 物への影響についても同様に動物間での種差等を考 慮しなければならない. 異物代謝やその種差, 化学 物質の感受性を理解することで, より精度の高い化 学物質のリスク評価が可能となり, 薬学の発展にも 貢献できるものと期待される.

このような背景をふまえて, 日本薬学会第 136 年 会（平成 28 年 3 月, 横浜）にて, シンポジウム S66「ヒトや野生生物における医薬品, 環境化学物 質の安全性評価の精度向上にむけて一代謝的活性 化, 種差, エピジェネティクスの観点から一」を企 画し, 化学物質の精度の高い安全性評価を目指して 異物代謝やその種差，エピジェネティック制御の観 点から議論させて頂いた。

その中で, はじめに大江知之博士（慶応大学薬学 部）に，「肝毒性を示す医薬品の代謝的活性化機構 の解析とそれに基づいた創薬戦略」というタイトル でご講演頂いた．医薬品の中には反応性代謝物の生 成により特異体質毒性など数々の毒性の原因とな り，市場から撤退したものもある．尿酸排泄促進薬 ベンズブロマロンの代謝的活性化機構についてご紹 介頂きながら, リスク回避の観点から代謝的活性化 を受けない医薬品候補品の創製のための予測評価や 代謝的活性化研究の重要性について議論頂いた.

佐能正剛（広島大学大学院医歯保健学研究院）か 
らは，「医薬品，一般化学物質の体内動態を考慮に 入れたヒトおよび野生生物におけるリスク評価」と いうタイトルで講演した。 その中で，マウスの肝臓 がヒトの肝細胞で置換されたヒト肝細胞移植キメラ マウスが，ヒトの体内動態を予測できることが期待 されるため，種差を考慮に入れた安全係数の見積も りに貢献できる可能性や, 野生生物においては, 力 エルの自然変態に対する影響をエンドポイントとし た化学物質のリスク評価について議論した.

水川葉月博士（北海道大学大学院獣医学研究科） からは，「非実験動物における化学物質代謝能の特 徵と種差」というタイトルでご講演頂いた。異物代 謝の動物種差に関する知見は，一部の実験動物を除 くとほとんどの生物種で十分に解明されていない. ヒトの夕ならず野生生物, 家畜やペット動物におけ る化学物質の毒性影響を考える上で重要となる。特 にグルクロン酸抱合や硫酸抱合などの第 II 相反応 の種差を解明するため, in vitro, in vivo レベル及び ゲノム情報を用いた評価について議論頂いた。

ここまでは，異物代謝やその種差に関する観点か らの講演であったが，続いてエピジェネティック制 御の観点からの議論も行つた.

まず，五十嵐勝秀博士（星薬科大学先端生命科学 研究所）からは，「エピジェネティック毒性研究の 現状と今後の展開」というタイトルでご講演頂い た。その中で，化学物質がエピジェネティック制御 に影響し，生体に好ましくない作用を及ぼす現象を 「エピジェネティック毒性」と定義し, 重点的な研 究の必要性を議論された。エピジェネティクスが化
学物質の長期にわたる影響や化学物質を含む環境要 因による疾患素因形成を説明し得る可能性があり， その評価モデルの構築など解析技術の大きな進展に 伴うブレイクスルーにより現象の理解が進むことが 期待される.

最後に, 木村朋紀（摂南大学理工学部）からは, 「金属曝露がもたらすエピジェネティックな変化と その分子機構」というタイトルで講演した。近年, 様々な金属のエピジェネティックな作用が知られる ようになり，生体における金属毒性とエピジェネ ティックな作用の関係について注目される，その中 で，6価クロム曝露によるエピジェネティックな変 化が，金属の解毒に働くメタロチオネインの誘導を 阻害することが明らかとなり，化学物質感受性を把 握するためも，有害金属によるエピジェネティック な変化とその機序を解明していく重要性について議 論した.

現状では，異物代謝反応による毒性発現，種差や エピジェネティックな視点が化学物質の安全性評価 に十分には生かされているとは言い難い。本誌上シ ンポジウムにおいて，大江博士，水川博士，五十嵐 博士，木村より異物代謝系と種差，あるいはエピジ エネティックな制御系を例に挙げ，ヒトはもちろん のこと，野生生物への影響評価をする上で考慮すべ き要因や今後の展望について紹介させて頂き，その 成果から, 医薬品や一般化学物質のヒト及び野生生 物における毒性・安全性評価の精度向上につなげた いと考えている. 